\title{
SPATIOTEMPORAL CHANGES IN ATMOSPHERIC DEPOSITION RATES ACROSS THE CZECH REPUBLIC ESTIMATED IN THE SELECTED BIOMONITORING CAMPAIGNS. EXAMPLES OF RESULTS AVAILABLE FOR LANDSCAPE ECOLOGY AND LAND USE PLANNING
}

\author{
IVAN SUCHARA, JULIE SUCHAROVÁ, MARIE HOLÁ
}

\begin{abstract}
Silva Tarouca Research Institute for Landscape and Ornamental Gardening, Květnové náměstí 391, CZ-252 43 Průhonice, Czech Republic, email: suchara@vukoz.cz, sucharova@vukoz.cz,hola@vukoz.cz.
\end{abstract}

Received: $10^{\text {th }}$ February 2015, Accepted: $5^{\text {th }}$ May 2015

\begin{abstract}
Several large-scale and fine-scale biomonitoring surveys were carried out in the Czech Republic to estimate current and long-term accumulated atmospheric deposition rates using moss, spruce bark and forest floor humus as bioindicators since the end of 1980s. The results of the bioindicator analyses significantly correlated with available figures of deposition rates detected at the EMEP or Czech national measurement stations.

The moss monitoring programmes revealed position of about 7 hot spots of high deposition loads of about 35-40 elements and indicated spatiotemporal decrease in the element deposition rates caused by restructuralization of industry, desulphurization of coal power plants and ceased distribution of leaded petrol. The deposition loads of toxic and risk elements have significantly decreased since the end of 1980s; however, increasing atmospheric deposition rates of reactive nitrogen has been bioindicated recently. The fine-scale moss monitoring campaigns, for example, delimited deposition zones around selected emission sources, revealed changes in deposition rates after introducing new technologies or delimited contaminated area in the surroundings of a chlor-alkali plant after a catastrophic flood episode. Deposition ranges of main pollution sources were mapped depicting the aerial distribution of stable lead isotopic ratios in moss, because the isotopic ratios are highly specific for each pollution source.

Monitoring the spruce bark parameters enabled to recognise the distribution of acid rain, dust and sulphate deposition rates and their spatiotemporal changes across the country between 1987 and 2010. The bark investigations along altitudinal profiles showed diminishing effect of air pollution on spruce bark parameters with increasing elevation. This phenomenon can be explained by a decreasing capacity of reduced tree crowns to trap air pollutants in the mountain environment.

The mapping of element content in forest floor humus revealed position of long-term spots of high accumulation of industrial pollutants and Chernobyl-derived ${ }^{137} \mathrm{Cs}$ in forests. Knowledge of these hot spots is important for health and environmental protection mainly in the areas where most of the former emission sources were cancelled and the current low atmospheric deposition rates may make a false impression of the clean landscape.
\end{abstract}


The data of the Czech national moss biomonitoring surveys were accepted and stored in the database of UN ECE ICP-Vegetation for checking of air pollution and its possible effecs on vegetation in Europe.

Key words: Atmospheric deposition; Biomonitoring; Moss; Bark; Humus; Czech Republic

\section{INTRODUCTION}

In order to protect the environment and health the concentrations of major air pollutants have been controlled in Europe by the Convention on Long-Range Transboundary Air Pollution (CLRTAP) and subsequent eight daughter protocols. A network of measurement stations of the European Monitoring and Evaluation Programme (EMEP) monitors local air pollution and transboundary air pollution transport. EC Directived (e.g., EU Directive 2008/50/EC) established the need to improve the monitoring and assessment of air quality including the deposition of pollutants and reciprocal exchange of information and air quality data within the Member States, etc. Monitoring at the measurement stations of national or European (EMEP) networks is expensive and hence it is focused on only few biologically active elements and compounds (e.g., $\mathrm{SO}_{\mathrm{x}}, \mathrm{NO}_{\mathrm{x}}, \mathrm{O}_{3}, \mathrm{PM}, \mathrm{Cd}, \mathrm{Hg}, \mathrm{Pb}$ and selected POPs). Deposition rates and effects of many other elements with biological effects (e.g., Be, Li, Th, $\mathrm{Tl}$, rare earth elements, etc.) have not been properly investigated in air quality control programmes.

The multielement biomonitoring surveys, using suitable plant biomonitors (Markert et al., 2004) can provide information about long-term and large-scale atmospheric deposition rates of elements. The large-scale biomonitoring programmes using selected bioindicators were introduced in the Czech Republic in the end of 1980s. The bioindicators are commonly available elsewhere in the landscape and the bioindicated air quality parameters can be related to the particular sampling sites within ecosystems. The following three bioindicators and their use in the Czech national biomonitoring programme are introduced.

Pleurocarpous mosses, such as Pleurozium schreberi and Scleropodium purum species can effectively adsorb deposited positively charged air pollutants on pectines and cell structures. Moss monitoring method was validated and tested to large-scale estimate current atmospheric deposition rates of elements between 1970 and 2000 (e.g., Rühling \& Tyler, 1970; Ross, 1990; Berg \& Steinnes, 1997). In the frame of UN ECE ICP-Vegetation programme more than 30 European countries have monitored the current element content in mosses at about 7000 sampling sites in five-year intervals since 2000. The Czech national moss surveys since 1991 have mapped element content distribution both within the whole county and in a fine map scale around selected emission sources.

Outer tree bark (rhytidome) is composed of reminds of dead tissue full of empty cells. Rhytidome on tree trunks has a considerable capacity to retain (e.g., spruce > oak > pine bark) dissolved or particulate matters presented in stemflow water or in the circumjacent atmosphere. Tree bark extract parameters were frequently used to estimate ground annual mean $\mathrm{SO}_{2}$ concentrations and acid rain loads in the past (e.g., Grodzińska, 1971; Härtel \& Grill, 1972). Later, bark analyses have been used to estimate air pollution by heavy metals, radionuclides, persistent organic pollutants, etc. (e.g., Kuik \& Wolterbeek, 1994; Schulz et al., 1999; Bellis et al., 2001).

Forest floor humus $\left(\mathrm{H}, \mathrm{O}_{\mathrm{h}}\right.$ horizon) is an important long-term sink for atmospheric deposition loads. Mainly cations presented in rain, and throughfall and stemflow waters are effectively and firmly adsorbed on negatively charged humus matter with adsorption 
Suchara I., Sucharová J., Holá M.: Spatiotemporal changes in atmospheric deposition rates across the Czech Republic estimated in the selected biomonitoring campaigns. Examples of results available for Landscape Ecology and Land use Planning

capacity up to $550 \mathrm{meq} 100 \mathrm{~g}^{-1}$ (Goldschmidt, 1937; Stevenson, 1994). Atmospheric deposition has been accumulated in humus for life time of a humus floor. However, natural erosion, bioturbation and human activities in forests may mixture forest floor humus and mineral soil materials and bias the atmospheric deposition records in humus. Hence the archived pollution signals have been frequently detected in peat bog cores due to a possible less damaged peat profiles and high time-resolution (millennial to decadal). Anyway, in spite of some difficulties forest floor humus was successfully used as a long-term passive sampler of atmospheric deposition rates in several large-scale campaigns (e.g., Låg \& Steinnes, 1978; Knoth et al., 2006; Zhiyanski et al., 2008; Reimann et al., 2009).

The aim of this paper is to provide a short review of the main Czech national biomonitoring programmes and introduce selected results showing spatiotemporal changes in deposition rates in the landscape and point out on some possible threats to health and environment. Results of the biomonitoring surveys can explain many environmental changes running currently in the landscape and serve as a basis for the landscape sustainable utilization and effective land use planning.

\section{MATERIAL AND METHODS}

\section{Study area}

The investigations at the scale of the Czech Republic $\left(78,866 \mathrm{~km}^{2}, 10.5 \mathrm{~m}\right.$ inhabitants) were carried out between 1987 and 2010. For the biomonitoring campaigns a network of 195-280 permanent monitoring plots and density of about $15 \times 15 \mathrm{~km}$ was introduced in coniferous forests. When the sampling plot was affected by logging or other sort of stand disruption the replacement plot was selected as short as possible. In parallel, several fine scale biomonitoring campaigns were realised using denser sampling networks, e.g., $2 \times 2 \mathrm{~km}$ to delimit pollution zones around selected individual pollution sources.

\section{Collecting and processing of samples}

Moss samples were collected in periods of five years (1991, 1995, 2000, 2005 and 2010. The biomonitoring activities followed validated methods of sampling and processing of samples. A composite sample mainly of Pleurozium schreberi or Scleropodium purum moss from each sampling plot consisted from 7-10 moss subsamples collected at the ground under canopy gaps. The samples were hand-cleaned in laboratory to remove dead moss parts and adventitious material. The air dried moss samples were homogenised and archived for analysis. More details are available in the moss survey protocols (e.g., http://icpvegetation. ceh.ac.uk/manuals/moss_survey.html).

In the tree bark monitoring campaigns (1987-2010) the outer bark was collected from 6-10 spruce trees 60-90- year old at each monitoring plot. Chips of outer bark were lightly peeled round the trunks at a height of $1.30 \pm 0.10 \mathrm{~m}$ above ground. Bark collection was avoided at spots covered by epiphytes, polluted by resin or bird droppings. The samples from individual trees were treated separately. The air dried bark specimens were pulverised in a mill and sieved to get a fine bark portion $(\leq 1.5 \mathrm{~mm})$ and a coarser portion $(1.5-3.0 \mathrm{~mm})$ for further analyses. More details were published, for example, in Suchara et al. (2014).

In some large-scale and fine-scale biomonitoring surveys humus samples from the $\mathrm{O}_{\mathrm{h}}$ horizon of a forest floor were cut out using a plastic cylinder with a 105 -mm-diameter. Seven subsamples were gathered in one composite sample at each sampling plot. Sites of evidently damaged forest floor were avoided and humus specimens with mineral content exceeding 
25-30\% were resampled. The air dried humus was sieved and homogenised as described in literature (e.g., Suchara \& Sucharová, 2002).

\section{Chemical analyses}

The element concentration in plant and humus samples was determined after digestion of the samples in a mixture of $\mathrm{HNO}_{3}+\mathrm{H}_{2} \mathrm{O}_{2}$ in Teflon vessels using a closed microwave digestion system (Sucharova \& Suchara, 2006). The analyses were carried out by inductively coupled plasma mass spectrometry (ICP-MS OES, ICP-MS, and ICP-MS-DRC II). Before 1995 the element concentrations in samples were determined using atomic absorption spectrometry (AAS-GTA). The total mercury concentrations were detected by an AMA-254 atomic absorption spectrometer. Moss, plant and humus reference materials were analysed in parallel to check quality of the analytical results. Content of total nitrogen was determined directly in the solid homogenised samples through a LECO Tru-Spec CN determinator.

Active reaction $\left(\mathrm{pH}-\mathrm{H}_{2} \mathrm{O}\right)$ in water extracts of the fine bark portion ( $4 \mathrm{~g}: 16 \mathrm{ml}$ for 48 hours) and in humus or soil extracts $(10 \mathrm{~g}: 50 \mathrm{ml}$ for $30 \mathrm{~min}$.) was determined using a combination glass/pH electrode. Commercial buffer solutions were used to standardise the $\mathrm{pH}$ measuring system. The results were related to a reference temperature $25^{\circ} \mathrm{C}$.

In water extracts of the coarse bark fraction $(4 \mathrm{~g}: 80 \mathrm{ml}$ for 24 hours) were detected total electric conductivity and content of soluble sulphates. The measuring system of a WTW conductometer and a WTW electrode was calibrated by a standard solution of $\mathrm{KCl}$. The detected values of the electric conductivity were related to a reference temperature of $25^{\circ} \mathrm{C}$. The concentration of sulphates in bark extracts was detected turbidimetrically after precipitation of sulphates by $\mathrm{BaCl}_{2}$ at $420 \mathrm{~nm}$ wavelength using a SPEKOL 10 spectrophotometer with a TK turbidimetric attachment. The measuring system was calibrated by standard $\mathrm{K}_{2} \mathrm{SO}_{4}$ solutions (Kosmus \& Grill, 1986).

The ${ }^{137} \mathrm{Cs}$ specific activities in the bark and humus samples were detected in the National Radiation Protection Institute in Prague by an accredited method using gamma spectrometry in the HPGe detector of relative efficiency $15-30 \%$ for 24-72 hours. The measured results were corrected on radioactive decay of ${ }^{137} \mathrm{Cs}$ related to the relevant sampling dates (Suchara et al., 2011).

\section{Processing the analytical results}

Basic statistics, regression analysis and multifactorial analyses of analytical results were carried out using mainly StatSoft Statistica and Microsoft Excel software. Distribution of element concentrations in contour maps was created using the Surfer programme (Golden Software Inc.) and linear model was applied for interpolating the site median values. Bar diagrams were constructed using Microsoft Excel software. A schema of the terrain vertical profiles was constructed using a drawing ability of the free available map for cyclists (Cykloatlas on-line - cykloserver, 2014).

\section{RESULTS AND DISCUSSION}

\section{Can the bioindicator parameters estimate the real deposition rates correctly?}

It is nearly generally accepted that moss, bark and forest floor humus are passive samplers of atmospheric deposition loads. These bioindicators trap and accumulate air pollutants with various efficiency during different intervals of their living terms. Anyway, one may wonder if the detected biomonitoring parameters (elements concentrations, $\mathrm{pH}$ values, electric conductivity, etc.) significantly correspond with the deposition rates detected by another 
Suchara I., Sucharová J., Holá M.: Spatiotemporal changes in atmospheric deposition rates across the Czech Republic estimated in the selected biomonitoring campaigns. Examples of results available for Landscape Ecology and Land use Planning

independent and validated method. Hence the figures from our biomonitoring surveys were correlated with the data detected at air quality measurement stations or with relevant interpolated data related for the biomonitoring sampling sites.

The atmospheric deposition rates across Europe have been determined at measurement stations (e.g., ca 70 investigate heavy metals and 55 reactive nitrogen) operating in the frame of the European Monitoring and Evaluation Programme (EMEP). Besides two EMEP stations the Czech national network for measuring deposition rates includes about 40 stations (e.g., Ilyin et al., 2012). However, deposition loads of only few chemical elements and compounds (e.g., S, N, H, F, Cl, Pb, Cd, (Hg), Ni and some POPs) have been determined at these stations. The deposition figures for remaining majority of elements, frequently toxic or biologically active, have not been measured at these measurement stations at all. However, the territorial "background" values of the bioindicator data can be adopted from biomonitoring surveys carried out in the cleanest territories (e.g., Greenland and Lapland). Sometimes the background bioindicator parameters are estimated from lognormal distribution of territorial bioindicator data sets.

Several regression analyses of element concentrations in moss and EMEP element deposition data were conducted by the EMEP and ICP Vegetation experts (e.g., Harmens et al., 2012; Schröder et al., 2012). These studies found out significant spatial correlations between normalised modelled EMEP deposition data for total $\mathrm{Cd}, \mathrm{Pb}, \mathrm{Hg}$ and $\mathrm{N}$ and normalised concentrations of these elements in moss bioindicators mainly in humid climate of Scandinavia and in some Central European countries, the Czech Republic included. The correlation coefficients for the whole Europe reached relatively high values $(r=0.45-0.94)$. For the CZ territory and a long period 1990-2010 the detected concentrations of $\mathrm{Cd}, \mathrm{Pb}, \mathrm{Hg}$ and $\mathrm{N}$ in moss correlated well with the EMEP modelled deposition data $\left(\mathrm{r}_{\mathrm{Cd}}=0.78, \mathrm{r}_{\mathrm{Pb}}=\right.$ $0.66, r_{\mathrm{Hg}}=0.48$ and $\mathrm{r}_{\mathrm{N}}=0.79$ ). However, detected concentrations of remaining elements in moss cannot be checked due to lack of the EMEP or other independent large-scale deposition data for these elements.

No European-scale bark survey results were available for comparison with the EMEP data. However, in the Czech Republic, the detected bark parameters tightly correlated with the atmospheric deposition figures determined at stations situated close the bark sampling sites. For example, the bark parameters investigated (1987-2010) in a forest adjacent to the meteorological observatory Košetice $\left(49^{\circ} 34^{\prime} 25^{\prime \prime} \mathrm{N} ; 15^{\circ} 04^{\prime} 50^{\prime \prime} \mathrm{E}\right)$ were correlated with the available data of deposition rates (http://portal.chmi.cz/files/portal/docs/ruzne/vystava /CISTOTA/12.pdf, http://www.chmi.cz/files/portal/docs/uoco/isko/grafroc/groce/gr12e/png /f3-23.png). Not only tight correlations between the bark parameters and the measured deposition rates were found but surprisingly, very similar speed of bark and deposition recoveries were revealed as well. For example, the annual medians of spruce bark extract reactions $\left(\mathrm{pH}-\mathrm{H}_{2} \mathrm{O}\right)$ significantly correlated $(\mathrm{r}=0.95)$ with the annual mean reaction of wet deposition detected at the station. The recovery (1989-2010) of acidified spruce bark ran nearly in the same speed as the acid wet deposition recovery: $\mathrm{pH}_{\text {bark }}=0.042 \times$ year -89.89 ; $\mathrm{pH}_{\text {wet dep. }}=0.037 \times$ year -68.45 . Similarly, well correlation was found $(\mathrm{r}=0.88-0.92)$ for the medians of the annual contents of soluble sulphates in bark and mean annual wet $\mathrm{SO}_{4}-\mathrm{S}$ deposition rates at Košetice.

The integrated amounts of pollutants in forest floor humus cannot be reliably related to the absolute deposition loads due to the lack of emission-deposition data from the past. The element content in humus can be modified by geogenic factors and biota activities (Sucharova et al., 2012). However, for the most recent period and "undisturbed" forest floor the element content in forest humus provided similar results as the remaining biomonitors 
and gave a reliable information about qualitative and quantitative composition of current atmospheric deposition loads (e.g., Novák et al., 2005; Reimann et al., 2007; Matysek et al., 2008).

\section{Bioindicated spatiotemporal changes in deposition loads}

So called "Black Triangles I and II", the areas in NW and NE part of the current Czech Republic, were commonly known as the most polluted sites in the country in the end of 1980s when the territorial emission amount peaked (Figure 1).

Fig. 1: Annual emissions of potentially acidifying pollutants in the Czech Republic between 1985 and 2012

(Information System of the Czech Hydrometeorological Institute, http://portal.chmi.cz/files/ portal/docs/uoco/isko/grafroc/grafroc_EN.html).

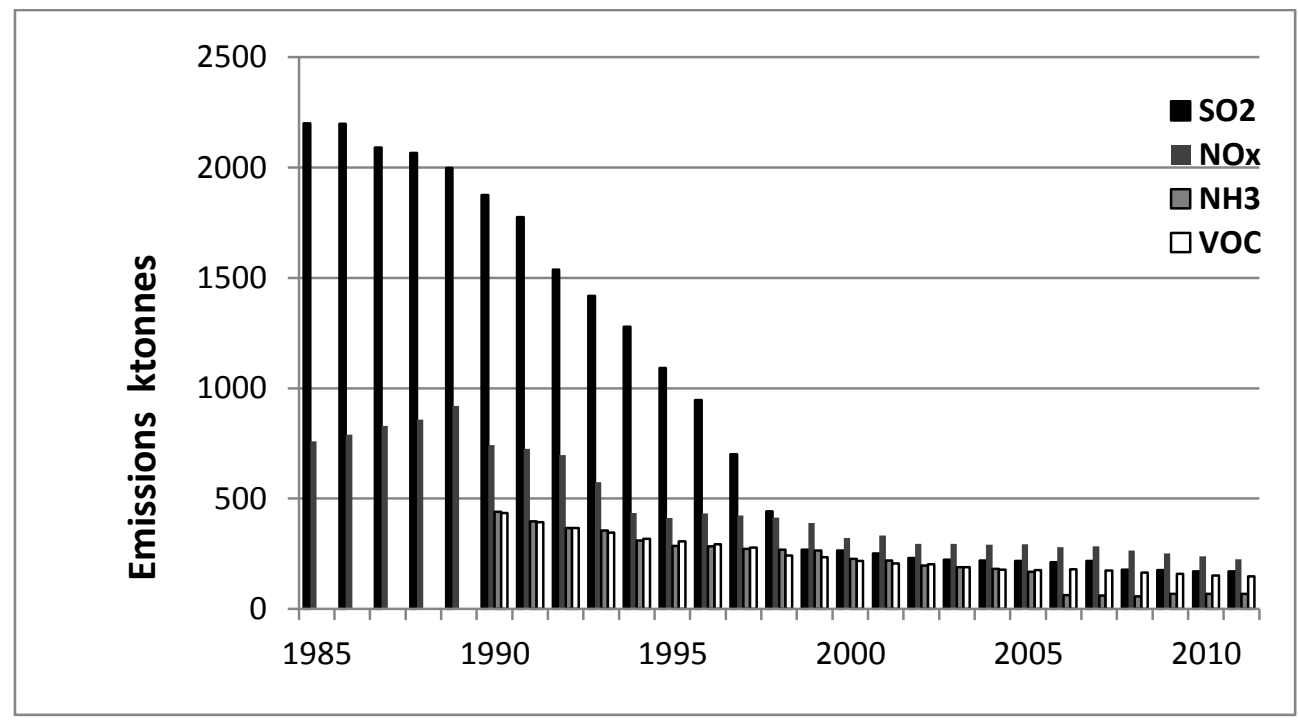

However, mapping the distribution of element contents in moss showed on the whole 7 hot spots affected by high levels of atmospheric deposition levels in 1991, 1995 and 2000 (Figure 2). Three hot spots (total $5,441 \mathrm{~km}^{2}$ ) of very high deposition rates of 13 elements were located in following parts of the country: 1. Brown coal basin and the close Ore Mts. in NW Bohemia (Black Triangle I) affected by industrial combustion of local brown coal, 2. N Bohemia around Liberec including the Jizerské Mts. and western part of the Giant Mts. affected by a close Polish coal power plant Turów and local metallurgical, engineering and glass industries, 3. Ostrava region and the adjacent Beskid Mts. (Black Triangle II) in NE corner of the country affected by operation of metallurgical, chemical and coal industries. Within the first hot spot very high deposition loads of, e.g., As, S, V, Hg, Be, Mo, Fe, Co, Cr, $\mathrm{Ni}, \mathrm{Pr}, \mathrm{Se}, \mathrm{Sr}$, etc. originated from industrial combustion of local brown coal and from dustiness associated with the mining activities were bioindicated. In the Black Triangle II area high deposition rates of $\mathrm{Ag}, \mathrm{Ba}, \mathrm{Bi}, \mathrm{Cd}, \mathrm{Cu}, \mathrm{Fe}, \mathrm{Pb}, \mathrm{Fe}, \mathrm{In}, \mathrm{Mo}, \mathrm{Sn}$, and $\mathrm{Zn}$ were detected. Around these hot spots were delimited neighbouring zones of high deposition loads, and the following additional 4 strictly defined hot spots (total 10,215 $\mathrm{km}^{2}$ ) of high deposition rates: 4. The blended surroundings of Př́ibram and Plzeň in SW part of central 
Bohemia affected by metallurgical industry, 5. A spot between Mělník and Kladno in W part of central Bohemia caused by operation of a brown coal power plant, metallurgical and engineering industries, and 6. An area including the NW surroundings of Hradec Králové and Pardubice regions in NE Bohemia affected by engineering and chemical industries. High deposition loads of, e. g., Ag, Bi, Fe, Hg, Mn, Mo, Ni, Pb, Sb, Se and $\mathrm{Sn}$ was bioindicated in these spots. The last and specific hot spot situated in southern Moravia was caused mainly by deposition of eroded soil particles from large fields. High content of mainly lithogenic elements (Al, Ba, Ga, Cr, Ni, lanthanides, U, Y, etc.) was detected by bioindicators in this area. Respecting the detected European range of element content in mosses (Markert et al., 1996) the area of low deposition rates was found in SW, S and SE Bohemia and in NE Moravia of total area about $36 \%$ of the Czech territory in the mid of 1990 s.

Fig. 2: Position of the main areas of the highest accumulation of 13-36 elements in the Czech Republic between 1991 and 2000. From the elements significantly more accumulated in moss in these hot spots are listed only some elements of the highest content in moss

\section{CZECH REPUBLIC - atmospheric deposition Biomonitoring 1991-2000}

\section{MOSS - ALL ELEMENTS}

Zones of relative deposition loads

$\square$ IV VERY HIGH

$\square$ III HIGH

$\square$ II MODERATE

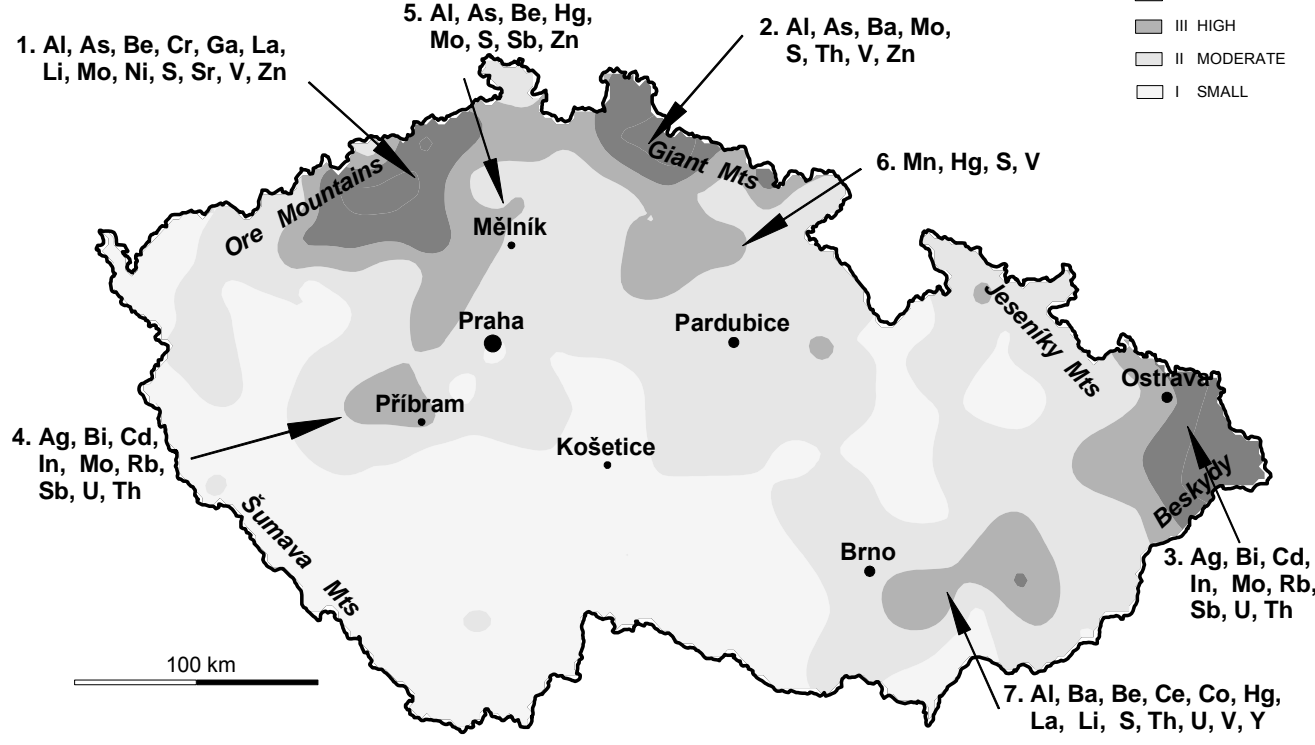

Knowledge of element concentrations in moss, production of moss and coefficients for element uptake efficiency (e.g., Ross, 1990; Thöni, 1996) enable to estimate the absolute deposition rates of individual elements in the deposition zones. For example, the mean bulk deposition $\left(\mu \mathrm{g} \mathrm{m}^{-2}\right.$ year $\left.^{-1}\right)$ of some selected elements in the Czech Republic in 1994-1995 was estimated to be as follows: $\mathrm{Al}-115,123$; $\mathrm{As}-239 ; \mathrm{Cd}-84 ; \mathrm{Fe}-114,208 ; \mathrm{Mo}-46 ; \mathrm{Pb}$ $-1,981 ; S-685,420$ and V -626 . Mainly in hot spots in western part of the Czech Republic 
the element content in moss significantly decreased, for example, by $65-75 \%$ for $\mathrm{V}$, As and $\mathrm{S}$, or by $25-50 \%$ for $\mathrm{Cu}, \mathrm{Cr}, \mathrm{Fe}, \mathrm{Ni}$ and $\mathrm{Zn}$ between 1991 and 1995 due to a closure of industrial works, restructuralisation of industry and significantly reduced amounts of combusted brown coal. Since local brown coal contains mineral admixtures containing nearly all chemical elements decreased burning of brown coal caused reduction in majority of element content in moss. The gradual diminishing in element content in moss was detected between 1990 and 2000. Steep and significant reduction of As and S contents in bioindicators was also supported by introduction of desulphurisation technologies in the Czech brown coal power plants between 1994 and 1998. The above mentioned hot spots of high deposition loads disappeared or were dramatically reduced in the area at the beginning of 2000s. However, the considerable decreasing of $\mathrm{Pb}$ content in moss went on up to about 2005 due to a phased out leaded petrol distribution between 1998 and 2000. For example, between 1990 and 2010 the average $\mathrm{Pb}$ content in moss within the Czech Republic decreased six times while the mean EMEP modelled Pb deposition diminished 4.5 times. The time decrease of selected element contents in moss is illustrated in Figure 3. After 2000 or 2005 the concentration of elements in moss has decreased slowly but largely significantly. The content of some elements in moss has fluctuated in accordance with increased or decreased deposition loads of eroded surface particles controlled by dry or wet vegetation periods.

Fig. 3: The temporal changes in the Czech national medians of the As, $\mathrm{Cd}$ and $\mathrm{Pb}$ contents in moss $\left(\mu \mathrm{g} \mathrm{g}^{-1}\right)$ between 1991 and $2010(\mathrm{n}=197-288)$. The error bars stand for the plus median absolute deviations

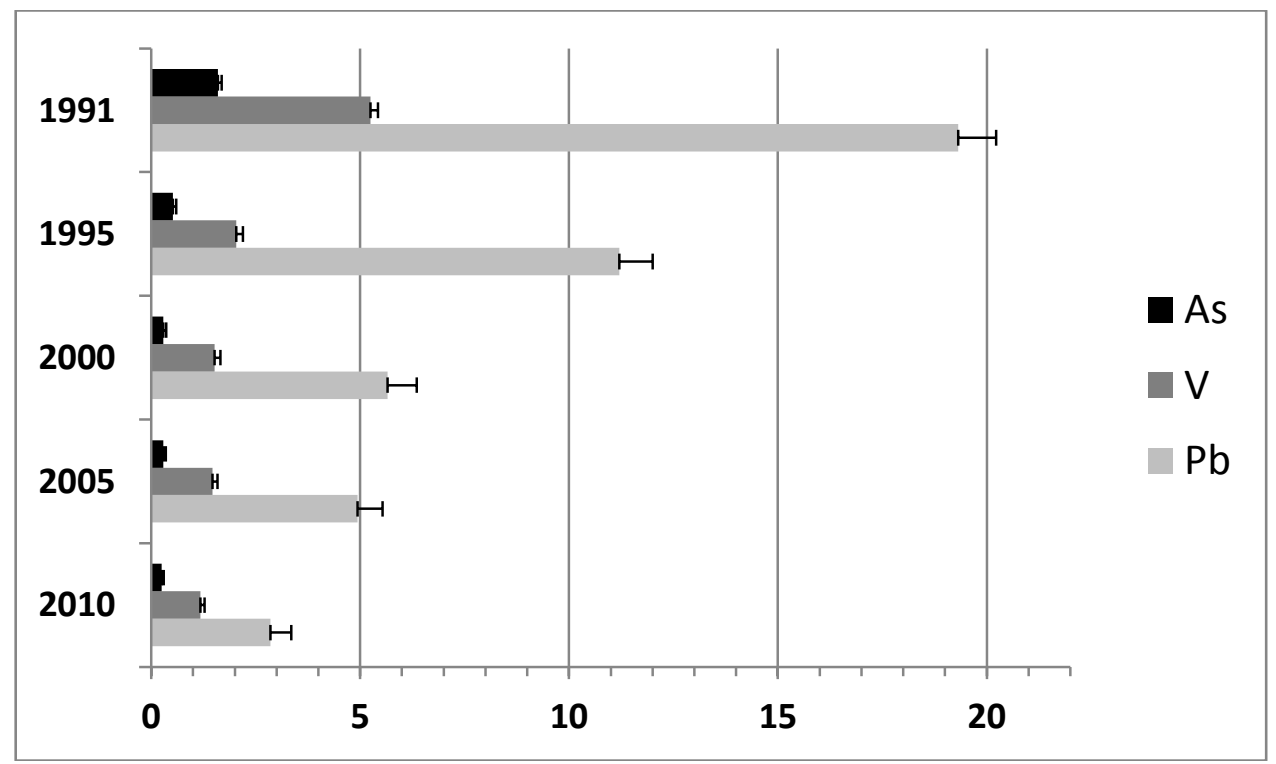

Total nitrogen in moss have decreased slowly or have not changed significantly while in many regions has risen. The reason is an increasing number of emission sources of nitrogen compounds (furnaces, cars, agricultural activities). The current (2010) distribution of total nitrogen content in moss across the Czech Republic is depicted in Figure 4. Approximately content of $1 \% \mathrm{~N}$ in moss corresponds to the mean annual deposition of about $15 \mathrm{kgN} \mathrm{ha}^{-1}$ year $^{-1}$. The areas of high nitrogen deposition risks (e.g., eutrophication, critical 
Suchara I., Sucharová J., Holá M.: Spatiotemporal changes in atmospheric deposition rates across the Czech Republic estimated in the selected biomonitoring campaigns. Examples of results available for Landscape Ecology and Land use Planning

loads exceedance, nitrogen saturation, etc.) have been precisely located interpolating data from more than 280 monitoring plots.

Fig. 4: Distribution of total nitrogen in moss $\left(\mu \mathrm{g} \mathrm{g}^{-1}\right)$ within the Czech Republic in 2010. One \% of nitrogen in moss $\left(10,000 \mu \mathrm{g} \mathrm{g}^{-1}\right)$ corresponds to the atmospheric deposition loads approaching to $15 \mathrm{kgN} \mathrm{ha}^{-1}$ year $^{-1}$

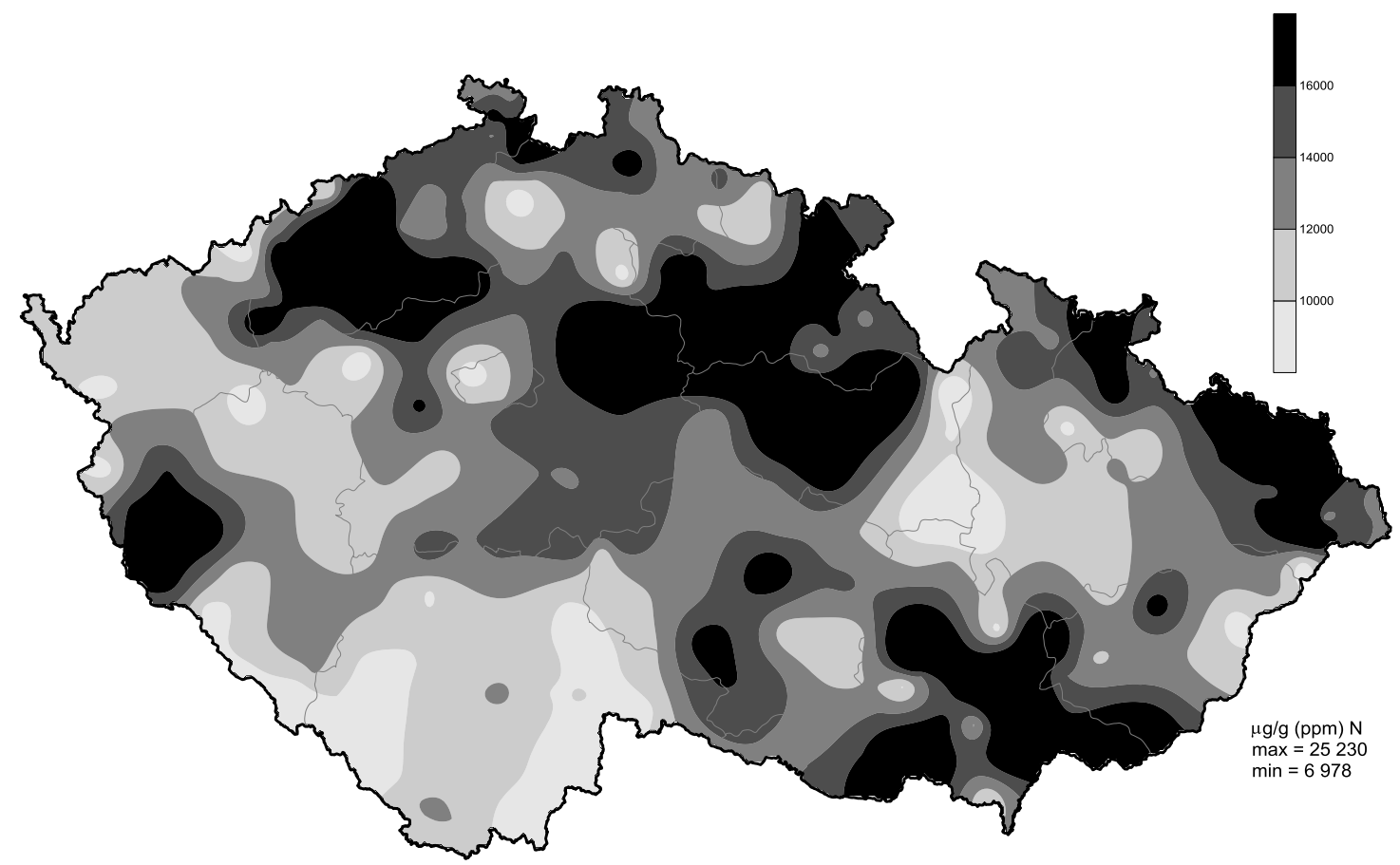

In all biomonitoring campaigns a special attention is paid to contamination of the landscape by toxic, carcinogenic and mutagenic elements (e.g., As, $\mathrm{Cd}, \mathrm{Hg}, \mathrm{Pb}$ ). Figure 5 documents the spatiotemporal changes of As content in moss across the Czech Republic between 1995 and 2010. The Czech national biomonitoring programmes inform about changes in about 40 element content in moss. Even if many of the monitored elements are biologically active (e.g., $\mathrm{Be}, \mathrm{Cr}, \mathrm{Cu}, \mathrm{Li}, \mathrm{Mo}, \mathrm{Ni}, \mathrm{REEs}, \mathrm{Se}, \mathrm{Th}, \mathrm{Tl}, \mathrm{Zn}$ ) landscape and health experts seem to be rather unconcerned about environmental and health effects of the high deposition loads of these elements in the country.

Special biomonitoring campaigns were accomplished to reveal the distribution of deposition zones around selected dominant pollution sources or to recognize changes in deposition load in their surroundings after introducing new technologies. For example, after modernization a secondary lead smelter in Př́bram a fine-scale biomonitoring campaign detected new distribution of zones of high deposition loads of 36 elements around the smelter 
(Sucharova \& Suchara, 2004). By chance a hot spot of high deposition rates of radioactive and lithogenic elements was revealed near heaps of the former uranium pits near Príbram.

Anyway, the current ranges of deposition loads from major pollution sources were mapped via distribution of stable lead isotopic contents in moss $\left({ }^{204} \mathrm{~Pb},{ }^{206} \mathrm{~Pb},{ }^{207} \mathrm{~Pb}\right.$ and $\left.{ }^{208} \mathrm{~Pb}\right)$. Since individual pollution sources emit lead with specific isotopic ratios (source fingerprint), the same isotopic ratio in bioindicators around the emission sources supports that they had been dominantly affected by the deposition coming from the given source. The distribution of lead isotopic ratios in moss was mapped in the Czech Republic in 2010 (Sucharová et al., 2014).

\section{Fig. 5: Spatiotemporal changes in As content in moss $\left(\mathrm{mg} \mathrm{kg}^{-1}\right)$ across the Czech Republic between 1995 and 2010}
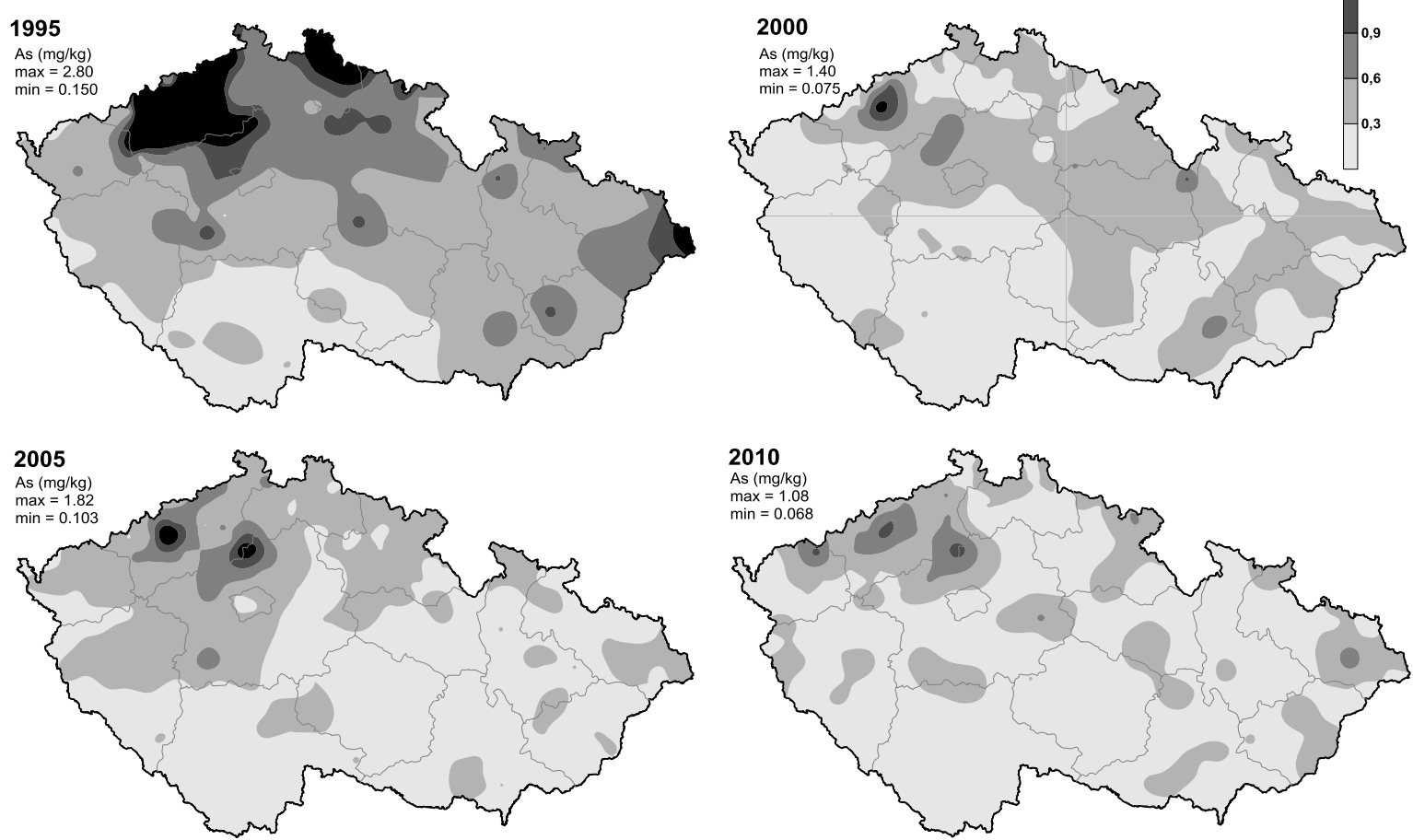

\section{Acid deposition}

Emission of acidic compounds, mainly $\mathrm{SO}_{x}$, peaked in the mid of 1980s. Forests decline, soil degradation, surface water acidification, corrosion of building materials and other negative effects caused by acid rains are well documented (e.g., Hruška \& Ciencala, 2003; Helliwell et al., 2014). Since the end of 1980s acid rain deposition levels in the Czech Republic have been estimated using spruce bark extract parameters.

Tree bark parameters, such as, reaction $(\mathrm{pH})$, electric conductivity and soluble sulphate content were found to be the effective indicators of areas most affected by high concentrations of $\mathrm{SO}_{2}$ in the past (e.g., Grodzińska, 1979). The figures about spruce bark 
parameters in the Czech Republic are available from 3 large-scale surveys (1995, 2005 and 2010). However, several local investigations of tree bark (oak, pine and spruce) were tested in the end of 1980s (e.g., urban and suburban greenery in Prague region, the surroundings of a power plant Tušimice and in details throughout the Pruhonice park). Changes in the extract parameters of spruce bark along vertical gradients in the Giant Mts. and the Ore Mts. were detected at the beginning of 1990s (e.g., Suchara, 1992; Suchara, 1993) and repeatedly in the end of 2000s. Extremely acid spruce bark extract reaction was measured in specimens from Prague's urban and suburban greenery $\left(\mathrm{pH}-\mathrm{H}_{2} \mathrm{O}=2.35-2.45\right)$ in 1987-1988. Small but significant seasonal fluctuation of bark reaction was found showing the highest and lowest $\mathrm{pH}$ values in autumns and in springs, respectively.

The mean reaction of spruce bark extracts was approaching to the value $\mathrm{pH}=2.5$ in the Czech Republic in the end of 1980s. Except for the Jeseníky Mts. on the North spruce bark in the whole northern half of the country showed high acidity, mainly in NW and $\mathrm{W}$ part of Bohemia. No wonder that then bark epiphytes disappeared in large areas of the country. The recovery of acidified bark has begun since 1988/1989. However, in 2005, in NW and W part of Bohemia the large area of high bark acidity still carried over. Even in 2010 an area of acid spruce bark $(\mathrm{pH}<2.9)$ was found in NW corner of the country probably caused by operation of a close coal power plant. A regression line for national medians of spruce bark reaction and time shows that median of the reaction of spruce bark extracts reached value $\mathrm{pH}=3.0 \mathrm{in}$ 2004-2005. Just then a general recolonisation of trees by acid-tolerant and nitrophilous lichens, e.g., Evernia prunastri, Hypogymnia physodes and Physcia adscendens was observable at the monitoring plots and elsewhere. The bark acidity has further decreased and the median $\mathrm{pH}$ values overran $\mathrm{pH}=3.50$ in 2009-2010. The current (2010) distribution of bark reaction throughout the Czech Republic can be seen in Figure 6 .

Fig. 6: Current (2010) distribution of spruce bark extracts reaction $\left(\mathrm{pH}-\mathrm{H}_{2} \mathrm{O}\right)$ in the Czech Republic

CZECH REPUBLIC Biomonitoring 2010
SPRUCE BARK $\mathrm{pH}-\mathrm{H}_{2} \mathrm{O}$

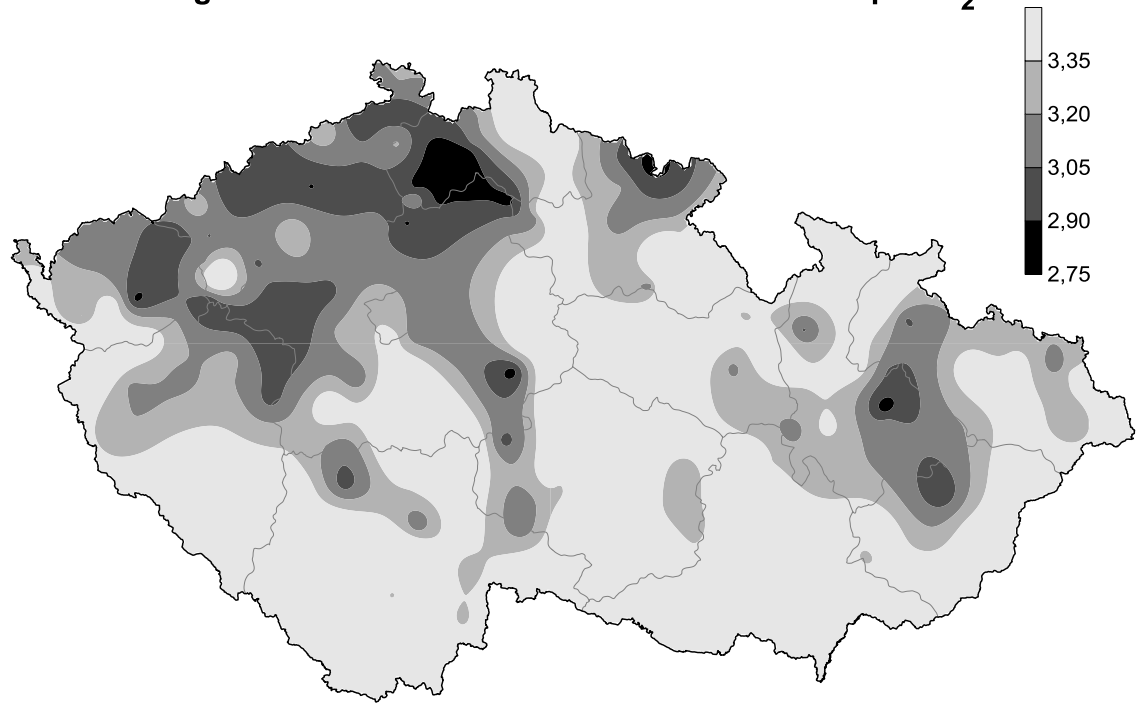


With the bark extract reaction tightly and significantly correlate electric conductivity, an indicator of dissolved charged particles and content of dissolved sulphates derived from $\mathrm{H}_{2} \mathrm{SO}_{4}$ the main component of acid rains in the past. Hence mapped distribution patterns of electric conductivity and sulphate content in bark extracts are very similar to the distribution of bark reaction. Abatement of hot spots of all investigated bark parameters resembled each other. For example, between 1990 and 2010 the median electric conductivity in the Czech Republic decreased from about 710 to $410 \mu \mathrm{S} \mathrm{cm}^{-1}$. With the similar speed decreased the soluble sulphate content in spruce bark from 5 to $2.6 \mathrm{~g} \mathrm{~kg}^{-1}$. More details were published in Suchara (2012) and Suchara et al. (2014).

The extensive damages of coniferous forests caused by heavy acid rains were observed in mountains in 1980s/1990s. The reason was increased wet deposition rates of acidifying pollutants, frequent occurrence of acid occult precipitation and their synergism with unfavourable climate. However, some epiphytes have survived the period of the highest loads of acid rains on trunks of considerable damaged trees just in mountains. Unexpectedly, our long-term investigation of bark parameters along mountain profiles revealed significantly higher bark acidity, electric conductivity and sulphate content in lowlands than in mountains. Similar trend has continued up to the present situation when concentration of $\mathrm{SO} 2$ in the atmosphere has dramatically decreased (Figure 7).

Fig. 7: The detected medians of the spruce bark extract reaction $\left(\mathrm{pH}-\mathrm{H}_{2} \mathrm{O}\right)$, electric conductivity $\left(\mu \mathrm{S} \mathrm{cm}^{-1}\right)$ and content of soluble sulphates $\left(\mathrm{mgSO}_{4}{ }^{2-} \mathrm{kg}^{-1}\right)$ at selected sites of the altitudinal transects crossing the Ore Mts. (1-4) and the Giant Mts. (5-14) and at a reference site (15) near the meteorological observatory Košetice in 1989 and 2008. The plus error bars represent median absolute deviations
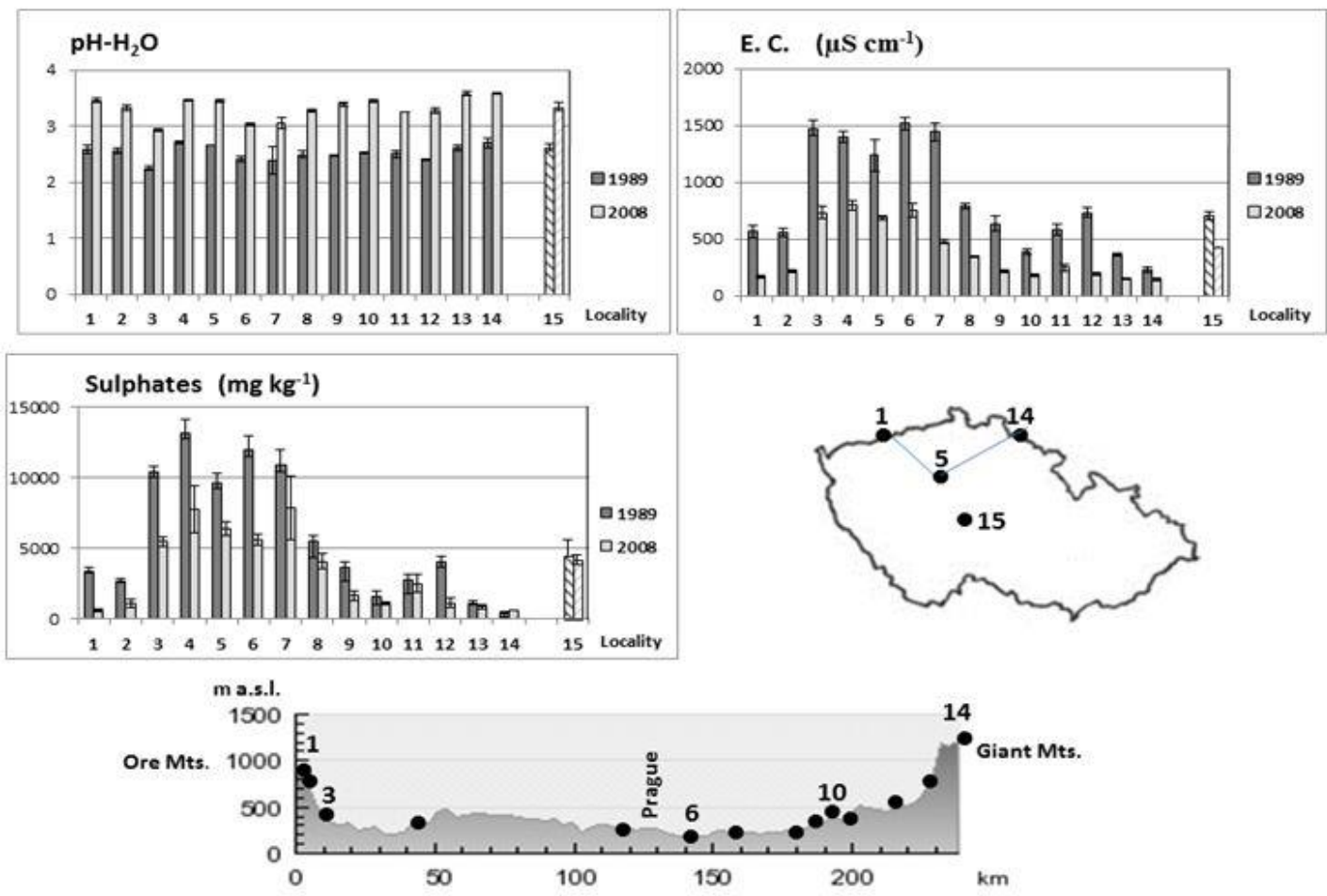
Suchara I., Sucharová J., Holá M.: Spatiotemporal changes in atmospheric deposition rates across the Czech Republic estimated in the selected biomonitoring campaigns. Examples of results available for Landscape Ecology and Land use Planning

The reason is that tree bark in lowlands is more affected by more polluted atmosphere due to frequent temperature inversions than tree bark in mountain stand. Even if trees along mountain ranges may be furthermore affected by acid occult precipitations the retention capacity of injured crowns of mountains trees to trap air pollutants is lower. That may be the main reason, why stemflow in mountains is less acid and cleaner than stemflow in a lower elevation.

\section{Archived long-term deposition loads}

The forest floor humus survey in 1995 (Suchara \& Sucharová, 2002) revealed relative very high cumulative loads of toxic and risk elements at $18 \%$ of the Czech Republic. These hot spots were located in the most industrialized parts of the country and matched to the areas of the high element content in moss determined in 1991 and 1995. The repeated humus surveys located the same hot spots and corroborated the firm and long-term binding of pollutants on humus particles. In the vicinity of major pollution sources or in highly industrialised areas forest floor humus archives obviously signals of deposited anthropogenic pollutants while effect of local bedrock chemistry is small. The typical ash content in coniferous litter is about $2 \%$ of dry weight. Content of "ash" (mainly mineral soil admixtures) in $\mathrm{O}_{\mathrm{h}}$ horizon of "intact" forest floor of coniferous forests is about 6-7\%. Typical ash content in humus samples collected from visibly undisturbed forest floor was respectively for pine and spruce stands 14 and 20\% (Suchara \& Sucharová, 2000). The highest difference in element contents between forest floor humus and bottom mineral soil was found for $\mathrm{Cd}, \mathrm{S}, \mathrm{Hg}, \mathrm{Se}$ and $\mathrm{Sb}$ (Sucharová et al., 2012). In clean areas unaffected by dust fall from extraction of local row materials forest floor may be affected by bedrock chemistry via soil-plant-soil element cycling and by bioturbation of forest floor. However, in spite of high bedrock type variability the background biogeochemical signal in forest floor humus is surprisingly low in the Czech Republic. Exception is higher accumulation of rock-derived $\mathrm{Ba}$, and $\mathrm{Cs}$ and $\mathrm{Rb}$, chemical analogues of $\mathrm{Ca}$ and $\mathrm{K}$, in forest humus. More details about forest floor humus chemistry throughout the Czech Republic are available in literature (Suchara \& Sucharová, 2002; Sucharová et al., 2011; Sucharová et al., 2012).

The fine-scale humus investigations around individual emission sources delimited, for examples, zones of very high and high content of $\mathrm{Hg}$ around a chlor-alkali plant near Neratovice (Suchara \& Sucharova, 2008), radioactive and lithogenic elements, such as, Al, $\mathrm{Be}, \mathrm{Fe}, \mathrm{Cr}, \mathrm{Ga}, \mathrm{Sc}, \mathrm{Th}, \mathrm{U}$, around a mill grounding stones from pit tips of the former uranium pits near Př́bram or accumulation zones of mainly chalkophylous elements (e.g., Ag, As, Bi, $\mathrm{Cd}, \mathrm{Cu}, \mathrm{In}, \mathrm{Pb}, \mathrm{Sb}, \mathrm{Sn}$ and $\mathrm{Zn}$ ) around a secondary lead smelter in Prríbram (Suchara \& Sucharová, 2004). The considerable contamination of forest humus, for example, by $\mathrm{Pb}$ was found in a radius exceeding $25-30 \mathrm{~km}$ from the lead smelter (Figure 8). High contamination of forest humus may cause transfer of toxic and risk elements to mushrooms, bilberries and other forest fruits and enter in food chains mainly if the smelter technology was renovated and since 1988 the amounts of metal emissions have been evidently lower. Unfortunately, it will take several tens or about one hundred years than the toxic and risk elements will be in humus naturally desorbed and washed out to deeper soil layers. However, forest fire in hot spots may promptly release these elements into the environment. Long-term heavy acid rains may degrade forest humus and pollutants adsorbed on more mobile fulvic acids can be transported by surface or ground waters far from the hot spots. 
Fig. 8: The distribution of the $\mathrm{Pb}$ content in forest floor humus $\left(\mathrm{mg} \mathrm{kg}^{-1}\right)$ in the surroundings of the secondary lead smelter in Příbram in 1989 after introducing a new technology (1988)

\section{DISTRIBUTION OF LEAD IN FOREST HUMUS}

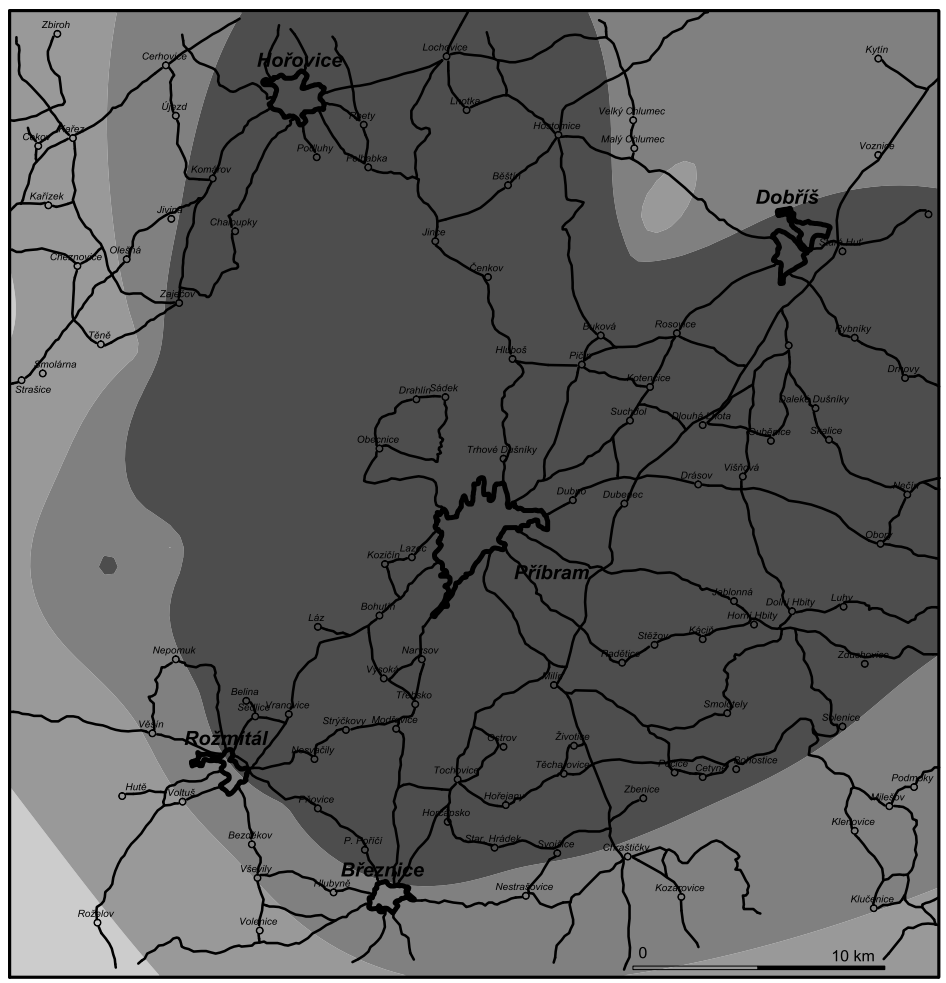

Lead in humus $(\mathrm{mg} / \mathrm{kg})$

$100 \quad 150 \quad 200 \quad 250$

The determined activities of ${ }^{137} \mathrm{Cs}$ in forest humus in 1995 and 2010 revealed the distribution of Chernobyl-derived ${ }^{137} \mathrm{Cs}$ in forest floor in the Czech Republic (e.g., Pilátová et al., 2011). The Czech national background (geometric mean) activity of ${ }^{137} \mathrm{Cs}$ in forest humus was $336 \mathrm{~Bq} \mathrm{~kg}^{-1}$ (related to summer 1995). About 10 main hot spots of ${ }^{137} \mathrm{Cs}$ activities exceeding $1,800 \mathrm{~Bq} \mathrm{~kg}^{-1}$ of total area about $10,000 \mathrm{~km}^{2}$ were detected between the Jeseníky Mts. in NE and the Sumava Mts. in SW margin of the country. Radiocaesium is firmly sorbet in illite (a soil clay mineral) structures in a transition zone between forest floor humus and mineral subsoil, typically $5-10 \mathrm{~cm}$ below the forest floor surface of coniferous forests. The position of these hot spots has not changed due to a negligible apparent speed of ${ }^{137} \mathrm{Cs}$ migration (0.1-1.2 mm year $\left.{ }^{-1}\right)$ and a long half-life of ${ }^{137} \mathrm{Cs}$ (30.2 years). Within these hot spots can be expected increased activities of ${ }^{137} \mathrm{Cs}$ in edible mushrooms and in meat and offal of wild boars, which like eating fruiting bodies preferentially of the effective ${ }^{137} \mathrm{Cs}$ accumulator Elaphomyces granulatus (Deer Truffle) mushroom. 
Suchara I., Sucharová J., Holá M.: Spatiotemporal changes in atmospheric deposition rates across the Czech Republic estimated in the selected biomonitoring campaigns. Examples of results available for Landscape Ecology and Land use Planning

\section{CONCLUSION}

Several large-scale and fine-scale biomonitoring campaigns using moss, spruce bark and forest floor humus as bioindicators of current and long-term accumulated atmospheric deposition rates have been carried out in the Czech Republic since the end of 1990. The detected values of the investigated bioindicator parameters significantly correlated with the figures of atmospheric deposition loads measured at the EMEP or national measurement stations.

The moss surveys can provide quickly and cheaply information about spatiotemporal changes of current deposition rates of about 35-40 chemical elements across the country. Figures from the moss biomonitoring programmes may be the only data about element deposition rates, which have not been determined at measurement stations of air quality, and which are biologically active (e.g., Be, Li, Se, Tl, Th, REEs, etc.). The moss biomonitoring is an effective tool for detecting effects of introducing new technologies on changes in deposition zones in the surroundings of emission sources. All results of the Czech moss surveys were accepted and stored in the UN ECE ICP-Vegetation database for checking of deposition loads in Europe and their environmental effects.

Tree bark parameters investigated in large-scale monitoring surveys effectively found out the spatiotemporal changes in deposition rates of acid rains (protons), dust and sulphates caused, for example, by decreasing amounts of combusted brown coal and desulphurization of coal power plants. The investigations of bark parameters revealed different impacts of air pollution in lowland and mountain environments on the bark parameters, which can provide supporting data for explaining of temporal and spatial changes in epiphyte distributions.

The large-scale forest floor humus campaigns reliably located and delimited areas of high accumulation of heavy metals and Chernobyl-derived radionuclides in the Czech Republic. The information about spots of long-term accumulated pollutants is important for land use planning in areas where the former emission sources have been cancelled and current deposition rates of industrial pollutants are low. For example, a large area of high accumulation of $\mathrm{Pb}$ and $\mathrm{Cd}$ delimited in large surroundings of Příbram smelter remains a threat for next decades even if current emission parameters have been substantially reduced.

Results of the biomonitoring campaigns may be a reliable basis for planning and long-term exploitation landscape of the country and for the further environmental and ecological investigations.

\section{REFERENCES}

Bellis, D., Ma, R., Bramall, N., McLeod, C.W., Chapman, N. \& Satake K. (2001). Airborne uranium contamination - as revealed through elemental and isotopic analysis of tree bark. Environmental Pollution, 114(3), 383-387.

Berg, T. \& Steinnes, E. (1997). The use of mosses (Hylocomium splendens and Pleurozium schreberi) as biomonitors of heavy metal deposition from: From relative to absolute deposition values. Environmental Pollution, 98(1), 61-71.

Cykloatlas on-line - cykloserver, (2014). Retrieved December, 2014 from web: http://www.cykloserver.cz/cykloatlas/\#pos=49.75000P15.75000P7.

ČHMÚ (2012). Material presented at an exhibition of the Czech Hydrometeorological Institute in Prague, April/May, 2012. (Košetice Observatory. In Czech). Retrieved December, 2014 from web: http://portal.chmi.cz/files/portal/docs/ruzne/vystava/ 


\section{CISTOTA/12.pdf.}

ČHMÚ (2013). Fig. III.23. The development of annual wet deposition at selected stations in 1991-2012, Czech Republic. In: Air pollution in the Czech Republic in 2012. Czech Hydrometeorological Institute, Prague. Retrieved December, 2014 from web: http://www.chmi.cz/files/portal/docs/uoco/isko/grafroc/groce/gr12e/png/f3-23.png.

EU DIRECTIVE 2008/50/EC OF THE EUROPEAN PARLIAMENT AND OF THE COUNCIL of 21 May 2008 on ambien air quality and cleaner air for Europe (2008). Official Journal of the European Union, 11. 6. 2008, L 162/1-162/44.

Frontasyeva, M., Harmens, H. \& Participants (2014). Heavy metals, nitrogen and POPs in European mosses: 2015 survey. Monitoring manual. UNECE ICP Vegetation. 26 pp. Retrieved July 17, 2014 from web: http://icpvegetation.ceh.ac.uk/publications/documents/ MossmonitoringMANUAL-2015-17.07.14.pdf.

Goldschmidt, V.M. (1937). The principles of distribution of chemical elements in minerals and rocks. Journal of the Chemical Society, 1937, 655-673.

Grodzińska, K. (1971). Acidification of tree bark as a measure of air pollution in Southern Poland. Bulletin de l'Academie Polonnaise des Sciences, Class 2 Série des Biologiques, 19(3), 189-192.

Grodzińska, K. (1979). Tree bark - sensitive biotest for environmental acidification. Environment International, 2(3), 173-176.

Harmens, H., Ilyin, I., Mills, G., Aboal J.R., Alber, R., Blum, O., Coşkun, M., De Temmerman, L., Fernández, J.Á., Figueira, R., Frontasyeva, M., Godzik, B., Goltsova, N., Jeran, Z., Korzekwa, S., Kubin, E., Kvietkus, K., Leblond, S., Liiv, S., Magnússon, S.H., Maňkovská, B., Nikodemus, O., Pesch, R., Pikolainen, J., Radnović, D., Rühling, Å., Santamaria, J.M., Schröder, W., Spiric, Z., Stafilov, T., Steinnes, E., Suchara, I., Tabors, G., Thöni, L., Turcsányi, G., Yurukova, L. \& Zechmeister, H.G. (2012). Country-specific correlations across Europe between modelled atmospheric cadmium and lead deposition and concentrations in mosses. Environmental Pollution, 166, 1-9.

Härtel, O. \& Grill, D. (1972). Die Leitfähigkeit von Fichtenborken- Extraktionen als emfindlicher Indikator für Luftverunreinigungen. European Journal of Forest Pathology, 2(4), 205-215.

Helliwell, R.C., Wright, R.F., Jackson-Blake, L.A., Ferrier, R.C., Aherne, J., Cosby, B.J., Evans, CH.D., Forsius, M., Hruska, J., Jenkins, A., Kram, P., Kopáček, J., Mayer, V., Moldan, F., Posch, M., Potts, J.M., Rogora, M. \& Schöpp, V. (2014). Assessing recovery from acidification of European surface waters in the year 2010: Evaluation of projections made with the MAGIC model in 1995. Environmental Science and Technology, 48, 1328013288 .

Hruška, J. \& Ciencala, E. (2003). Long-term acidification and nutrient degradation of forest soils - limiting factors of forestry today. Prague: Ministry for the Environment, 165 pp.

Ilyin, I., Travnikov, O., Varygina, M., Vana, M., Machalek, T. \& Hnilikova, H. (2012). Assessment of heavy metal pollution levels in the Czech Republic (EMEP case study). Joint MSC-E/CHMI Report. EMEP/ASC-E Technical Report 1/2012,58 pp. Meteorological Synthesizing Centre - East, Moscow and Czech Hydrometeorological Institute, Prague. (http://www.msceast.org/reports/1_2012.pdf)

Knoth, W., Mann, W., Meyer, R. \& Nebhuth, J. (2006). Humus from coniferous forests a reservoir for PBDE from air and deposition - analysis and quality control. Organohalogen Compounds, 68, 1163-1166. 
Suchara I., Sucharová J., Holá M.: Spatiotemporal changes in atmospheric deposition rates across the Czech Republic estimated in the selected biomonitoring campaigns. Examples of results available for Landscape Ecology and Land use Planning

Kosmus, W. \& Grill, D. (1986). Die Bedeutung verschiedener Parameter bei der Beurteilung von Immissionen anhand von Borkenanalysen am Beispiel des Stadtgebietes von Graz. Mitteilungen des Naturwissenschaftlichen Vereins für Steiermark, 116, 161-172.

Kuik, P. \& Wolterbeek H.Th. (1994). Factor analysis of trace-element data from tree-bark samples in The Netherlands. Environmental Monitoring and Assessment, 32(3), 207-226.

Låg, J \& Steinnes, E. 1978. Regional distribution of selenium and arsenic in humus layers of Norwegian forest soils. Geoderma, 20(1), 3-14.

Markert, B., Herpin, U., Berlekamp, J., Oehlmann, J., Grodzinska, K., Mankovska, B., Suchara, I., Siewers, U., Weckert, V. \& Lieth, H. 1996. A comparison of heavy metal deposition in selected Eastern European countries using the moss monitoring method, with special emphasis on the 'Black Triangle '. Science of the Total Environment, 193(2), 85-100).

Markert, B.A., Breure A.M. \& Zechmeister H.G. (2004). Bioindicators and biomonitors. Principles, concepts and applications. $2^{\text {nd }}$ impression, 997 pp. Amsterdam - Tokyo: Elsevier.

Matysek, D., Raclavska, H. \& Raclavsky, K. (2008). Correlation between magnetic susceptibility and heavy metal concentrations on forest soils of the eastern Czech Republic. Journal of Environment and Engineering Geophysics, 19(1), 13-26.

Novák, M., Kirchner, J.W, Fottová, D., Přechová, E., Jačková, I., Krám, P. \& Hruška. J. (2005). Isotopic evidence for processes of sulphur retention/release in 13 forested catchments spanning a strong pollution gradient (Czech Republic, central Europe). Global Biogeochemical Cycles, 19, GB4012, 14 pp. (Doi: 10.1029/2004GB002396).

Pilátová, H., Suchara, I., Rulík, P., Sucharová, J., Helebrant, J., \& Holá, M. (2011). Maps of distribution of ${ }^{137}$ Cs content in forest floor humus in coniferous forests within the Czech Republic in 1995. (In Czech). Zpráva SÚRO č. 25/2011, 8 pp. Report. Prague: National Radiation Protection Institute. (https://www.suro.cz/cz/rms/monitorovani-slozek-zivotniho -prostredi/mapy-obsahu-cs137-v-humusu-v-1995).

Reimann, C., Arnoldussen, A., Engelmaier, P., Filzmoser, P., Finne, T.E., Garrett, R.G., Keller, F. \& Nordgulen, $\varnothing$. (2007). Element concentrations and variations along a $120-\mathrm{km}$ long transect in southern Norway - Anthropogenic vs. geogenic vs. biogenic element sources and cycles. Applied Geochemistry, 22(4), 851-871.

Reimann, C., Engelmaier, P., Flem, B., Gough, L., Lamothe, P., Nordgulen, $\varnothing$. \& Smith, D. (2009). Geochemical gradients in soil O-horizon samples from southern Norway: Natural or anthropogenic? Applied Geochemistry, 24(1), 62-76.

Ross, H.B. (1990). On the use of mosses (Hylocomium splendens and Pleurozium schreberi) for estimating atmospheric trace metal deposition. Water, Air, and Soil Pollution, 50(1-2), 63-76.

Rühling, Å. \& Tyler, G. (1970). Sorption and retention of heavy metals in the woodland moss Hylocomium splendens (Hedw.) Br. et Sch. Oikos, 21(1), 92-97.

Schröder, W., Pesch, R., Harmens, H., Fagerli, H. \& Ilyin, I. (2012). Does spatial auto-correlation call for a revision of latest heavy metal and nitrogen deposition maps? Environmental Sciences Europe, 24, 20, 8 pp., (DOI: 10.1186/2190-4715-24-20).

Schulz, H., Popp, P., Huhn, G., Stärk, H.J. \& Schüürmann, G. (1999). Biomonitoring of airborne inorganic and organic pollutants by means of pine tree barks: I. Temporal and spatial variations. Science of the Total Environment, 232(1-2), 49-58. 
Stevenson, E.J. (1994). Humus chemistry. Genesis, composition, reactions. $2^{\text {nd }}$ Ed., 512 pp. Chichester: John Wiley \& Sons.

Suchara, I. (1992). Experience in air quality indication through leaf enzyme activities and bark extracts characteristics. In: Boháč, J. (ed.), Bioindicatores deteriorisationis regionis. Proceedings of the sixth international conference, (pp. 109-116), České Budějovice: Institute of Landscape Ecology.

Suchara, I. (1993). The use of some urban park woody species in an estimation of air pollution levels. Tree bark extract characteristics. Zahradnictví, Praha, 20(4), 241-260.

Suchara, I. (2012). Temporal and spatial changes in spruce bark acidity at the scale of the Czech Republic in the last two decades, and the current abundance of epiphytic lichen Hypogymnia physodes. Water, Air, and Soil Pollution, 223(4), 1685-1697.

Suchara, I. \& Sucharová, J. (2000). Distribution of long-term accumulated atmospheric deposition loads of metal and sulphur compounds in the Czech Republic determined through forest floor humus analyses. Acta Průhoniciana, 69, 1-177.

Suchara, I. \& Sucharová, J. (2002). Distribution of sulphur and heavy metals in forest floor humus of the Czech Republic. Water, Air, and Soil Pollution, 136(1-4), 289-316.

Suchara, I. \& Sucharová, J. (2008). Mercury distribution round the Spolana chlor-alkali plant (central Bohemia, Czech Republic) after a catastrophic flood, as revealed by bioindicators. Environmental Pollution, 151(2), 352-361.

Suchara, I. \& Sucharová, J. (2008). Distribution of 36 element deposition rates in a historic mining and smelting area as determined through fine scale biomonitoring techniques, Part II: Relative long-term accumulated atmospheric deposition levels. Water, Air, and Soil Pollution, 153(1-4), 229-252.

Suchara, I., Sucharová, J. \& Holá, M. (2014). The influence of contrasting ambient $\mathrm{SO}_{2}$ concentrations in the Czech Republic in 1995 and 2010 on the characteristics of spruce bark, used as an air quality indicator. Ecological Indicators, 39: 144-152.

Suchara, I., Rulík, P., Hůlka, J. \& Pilátová, H. (2011). Retrospective determination of ${ }^{137} \mathrm{Cs}$ specific activity distribution in spruce bark and bark aggregated transfer factor in forests on the scale of the Czech Republic ten years after the Chernobyl accident. Science of the Total Environment, 409(10), 1927-1934.

Suchara, I., Sucharová, J. \& Holá, M. (2014). The influence of contrasting ambient SO2 concentrations in the Czech Republic in 1995 and in 2000 on the characteristics of spruce bark, used as an air quality indicator. Ecological Indicators, 39, 144-152.

Sucharova, J. \& Suchara I. (2004). Distribution of 36 element deposition rates in s historic mining and smelting area as documented through fine-scale biomonitoring techniques. Part I: Relative and absolute current atmospheric deposition levels detected by moss analyses. Water, Air, and Soil Pollution, 153(1-4), 205-228.

Sucharova, J. \& Suchara I. (2006). Determination of 36 elements in plant reference materials with different $\mathrm{Si}$ contents by inductively coupled plasma mass spectrometry. Comparison of microwave digestions assisted by three types of digestion mixtures. Analytica Chimica Acta, 576(2), 163-176.

Sucharová, J., Suchara, I., Reimann, C., Boyd, R., Filzmoser, P. \& Englmaier, P. (2011). Spatial distribution of lead and lead isotopes in soil B-horizon, forest-floor humus, grass (Avenella flexuosa) and spruce (Picea abies) needles across the Czech Republic. Applied Geochemistry, 26(7), 1205-1214. 
Sucharová, J., Suchara, I., Hola, M., Marikova, S., Reimann, C., Boyd, R., Filzmoser, P. \& Englmaier, P. (2012). Top-/bottom-soil ratios and enrichment factors: What do they really show? Applied Geochemistry, 27(1), 138-145.

Sucharová, J., Suchara, I., Holá, M. \& Reimann C. (2014). Contemporary lead concentrations and lead stable isotope distribution in forest moss across the Czech Republic. Applied Geochemistry, 40, 51-60.

Thöni, L. (1996). Vergleich von Elementkonzentrationen in drei Biominitoringmoosen untereinander und mit Depositionsfrachten im Bulksammler nach Bergerhoff, Egg: Bundesamtes für Umwelt, Wald und Landschaft - Forschungsstelle für Umwelbeobachtung (BUWAL-FUB), 89 pp.

Zhiyanski, M., Bech, J., Sokolovska, J., Lucot, E., Bech, J. \& Badot, P. H. (2008). Cs-137 distribution in forest floor and surface soil layers from two mountains regions in Bulgaria. Journal of Geochemical Exploration, 96(2-3), 256-266. 